\title{
AGROGSTA
}

Journal Agroista. Vol. 5 ,No.2 November 2021

Journal home page: https://jurnal.instiperjogja.ac.id/index.php/AGI

ISSN : $2597-3835$

e-ISSN : : $2684-7019$

\section{EFEKTIFITAS ORYNET TRAP TERHADAP HASIL TANGKAPAN KUMBANG TANDUK PADA TANAMAN KELAPA SAWIT BELUM MENGHASILKAN}

\author{
Idum Satia Santi ${ }^{1}$, Elizabeth Nanik Kristalisasi ${ }^{1}$, Kelvin Rajh Singh ${ }^{1}$ \\ ${ }^{1}$ Department of Agrotechnology, Faculty of Agriculture, Stiper Agricultural Institute, \\ Yogyakarta, Indonesia \\ Corresponding author: idum@instiperjogja.ac.id
}

\begin{abstract}
ABSTRAK
Oryctes rhinoceros (Coleoptera: Scarabidae) atau dikenal sebagai kumbang tanduk merupakan hama yang cukup penting di perkebunan kelapa sawit, terutama bila menyerang tanaman belum menghasilkan. Penelitian bertujuan untuk mengkaji keefektifan orynet trap terhadap hasil tangkapan kumbang tanduk, serta pengaruhnya terhadap intensitas kerusakan. Penelitian dilaksanakan dengan membandingkan perangkap feromon + jaring (Orynet trap) dengan feromon+insektisida polidor. Hasil penelitian menunjukkan jumlah $\mathrm{O}$. rhinoceros yang tertangkap pada perlakuan feromon+perangkap jaring (orynet trap) lebih banyak daripada feromon+insektisida polidor. Tidak terjadi penambahan intensitas kerusakan tanaman setelah perlakuan feromon+jaring (Orynet trap), sebaliknya intensitas kerusakan tanaman meningkat sebesar $11,9-18,8 \%$ pada perlakuan feromon+insektisida polydor. Diharapkan, penelitian ini akan bermanfaat sebagai salah satu alternatif untuk pengendalian O. rhinoceros di perkebunan kelapa sawit.
\end{abstract}

Kata Kunci: Kelapa Sawit, O. rhinoceros, Orynet Trap. 


\section{PENDAHULUAN}

Tanaman kelapa sawit merupakan tanaman yang mempunyai arti ekonomi tinggi. Pengembangan perkebunan kelapa sawit sangat pesat di Indonesia, terutama di Sumatera dan Kalimantan. Kedua pulau tersebut mampu menghasilkan 95\% produksi minyak sawit mentah (crude palm oil/CPO). Tahun 2017 luas perkebunan sawit mencapai 16 juta ha, dengan produksi CPO Indonesia diprediksi mencapai 42 juta ton (Purba dan Sipayun, 2017).

Salah satu hama utama kelapa sawit adalah Oryctes rhinoceros L ( Coleoptera : Scarabidae) yang selanjutnya disebut kumbang tanduk. Serangan hama ini dapat menurunkan hasil sebesar $69 \%$ pada saat panen pertama dan menyebabkan kematian sebesar $25 \%$ pada tanaman belum menghasilkan (Sitinjak, 2018).

Kumbang tanduk disebut juga kumbang bibit atau kumbang nyiur karena menyerang tanaman kelapa sawit yang masih muda. Kumbang menggerek pucuk tanaman dan menyebabkan kerusakan di sekitar titik tumbuh. Serangan ini terkadang menyebabkan malformasi pada pupus. Kebun dengan serangan berat terkadang pada satu tanaman dapat digerek beberapa kali sehingga menyebabkan kematian tanaman (Purba, 2010).

Serangan O. rhinoceros pada tanaman muda dapat menyebabkan kematian. Saat hama ini mengebor pucuk tanaman biasanya juga merusak bagian daun muda yang belum terbuka, sehingga ketika daun terbuka akan terlihat bekas potongan yang simetris berbentuk segitiga atau seperti huruf $\mathrm{V}$. Akibatnya, mahkota daun tampak compang camping tidak teratur sehingga bentuknya tidak bagus lagi (Junaedi, et al., 2015).

Pengendalian $O$. rhinoceros dapat dilakukan secara mekanis, biologis dan kimia. Selama ini pengendalian yang telah dilakukan meliputi pengutipan larva dan kumbang, mengurangi breeding site hama, penggunaan jamur entomopatogen Metarhizium anisopliae (Herlinda, 2018). Pengendalian kumbang tanduk juga menggunakan perangkap feromon yakni ethyl 4-methyloctanoate untuk menarik kumbang jantan dan betina (Widyanto, 2014). Penggunaan insektisida sintetik ternyata kurang efektif, sifatnya tidak berkelanjutan dan mengakibatkan berbagai dampak negatif (Hasibuan, 2018). Pestisida kimia Polydor berbahan aktif lambda cyhalothrin yang mempunyai dampak negatif terhadap lingkungan dan menyebabkan hama menjadi resisten (Anonim, 2016).

Sehubungan dengan uraian di atas, maka perlu dikaji pengendalian hama $\mathrm{O}$. rhinoceros secara mekanik pada tanaman kelapa sawit dengan menggunakan perangkap jaring (orynet trap) yang dipasangkan melingkar pada daerah pupus tanaman kelapa sawit. Penelitian ini bertujuan untuk mengkaji keefektifan perangkap jaring (orynet trap) sebagai alternatif dalam pengendalian hama $O$. rhinoceros pada tanaman kelapa sawit belum menghasilkan (TBM). Keefektifan orynet trap dihitung dari hasil tangkapan imago 0. rhinoceros serta tingkat kerusakan karena serangan hama tersebut. Diharapkan hasil 
penelitian ini akan memberikan alternatif teknik pengendalian kumbang tanduk pada perkebunan kelapa sawit.

\section{METODOLOGI}

Penelitian dilaksanakan pada Kebun Simpang Perak (KSP) PT. Inti Indosawit Subur, Asian Agri Group, Desa Mekar Jaya, Pelalawan, Riau pada 29 Desember 2020 sampai 26 Januari 2021. Alat yang digunakan pada penelitian ini adalah gunting, penggaris, kayu, seng plat, cat yang digunakan untuk membuat plank penelitian, alat tulis dan knapsack sprayer. Bahan yang diperlukan dalam penelitian ini adalah jaring (net) yang berdiameter kecil, feromon trap, dan insektisida sintetik polydor dengan bahan aktif lamda sihalotrin konsentrasi $1 \%$.

Penelitian ini menggunakan Rancangan acak Lengkap (RAL) dengan 2 aras perlakuan yaitu $F+I P=$ Feromon (Ethyl 4-methyloctanoate) dengan Insektisida Polydor (Lambda cyhalothrin) dan F + PJ = feromon (Ethyl 4 - methyloctanoate) dan perangkap jaring (orynet trap) dengan 3 ulangan. Setiap perlakuan menggunakan sample 10 pokok. Data hasil penelitian dianalisis menggunakan sidik ragam (Analysis of Varian) pada jenjang nyata $5 \%$. Apabila terdapat perlakuan yang berbeda nyata, maka akan dilakukan uji lanjut dengan Duncan Multiple Test (DMRT) pada jenjang nyata 5\%. Pengamatan dilakukan 7 hari setelah pemasangan perangkap selama 28 hari dan dilakukan pada pukul 09.00-14.00 WIB. Parameter yang diamati adalah jumlah kumbang yang tertangkap serta intensitas kerusakan sebelum dan sesudah perlakuan.

\section{HASIL DAN PEMBAHASAN}

Oryctes rhinoceros merupakan hama tanaman kelapa sawit yang dapat mengakibatkan penurunan hasil, terutama pada tanaman belum menghasilkan. Untuk pengamatan penelitian dilakukan pada blok tanaman kelapa sawit varietas Topaz yang ditanam pada bulan Juli 2020. Berikut adalah persentase serangan O.rhinoceros pada blok penelitian (Tabel 1). 
Tabel 1. Data Sensus Serangan O. rhinoceros Pada Tahun 2020 (\%)

\begin{tabular}{|c|c|c|c|c|}
\hline Blok & Bulan & Jumlah sensus pokok & Jumlah pokok terserang & $\%$ \\
\hline \multirow[t]{5}{*}{$\mathrm{B} 20 \mathrm{a}$} & Sep & 5120 & 0 & 0,00 \\
\hline & Oct & 5120 & 5 & 0,10 \\
\hline & Nov & 5120 & 20 & 0,39 \\
\hline & Des & 5120 & 34 & 0,66 \\
\hline & Rerata & 5120 & 12 & 0,29 \\
\hline \multirow[t]{5}{*}{ B20b } & Sep & 4815 & 0 & 0,00 \\
\hline & Oct & 4815 & 7 & 0,15 \\
\hline & Nov & 4815 & 18 & 0,37 \\
\hline & Des & 4815 & 33 & 0,69 \\
\hline & Rerata & 4815 & 12 & 0,30 \\
\hline \multirow[t]{5}{*}{ B20c } & Sep & 4018 & 0 & 0,00 \\
\hline & Oct & 4018 & 9 & 0,22 \\
\hline & Nov & 4018 & 13 & 0,32 \\
\hline & Des & 4018 & 21 & 0,52 \\
\hline & Rerata & 4018 & 9 & 0,27 \\
\hline
\end{tabular}

Sumber : Data Sensus HPT PT KSP, 2020

Sensus serangan hama dimulai pada bulan September 2020. Kemudian intensitas serangan $O$. rhinoceros mulai terlihat pada bulan oktober dengan rata-rata $(0,10-0,22 \%)$ dimana pada saat tersebut pertama kali dilakukannya pengendalian dengan penyemprotan insektida polydor (lamda sihalotrin) dengan konsentrasi larutan $1 \%$. Intensitas serangan $O$. rhinoceros terus mengalami peningkatan pada bulan November dan intensitas serangan terbesar terjadi bulan Desember dengan rata-rata $(0,52-0,69 \%)$.

Perkembangan jumlah pokok yang terserang setiap bulan dalam setahun menunjukkan fluktuasi, dapat dilihat pada Gambar 1 sebagai berikut:

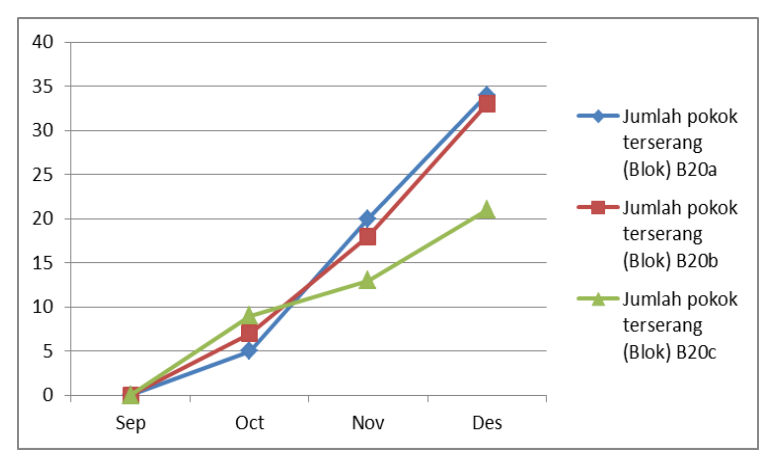

Gambar 1. Grafik Jumlah Pokok Terserang Tahun 2020

Sumber : Hasil Sensus HPT KSP, 2020 
Berdasarkan grafik di atas, dapat dilihat bahwa jumlah pokok terserang dari bulan September terus mengalami peningkatan sampai pada bulan Desember. Hal tersebut terjadi karena pada November dan Desember terdapat banyak hari libur dan beberapa kali perusahaan melakukan pembatasan hari kerja sebagai pencegahan dari tersebarnya wabah Covid-19. Hal tersebut menyebabkan pengendalian rutin yang dilakukan Kebun Simpang Perak dengan melakukan penyemprotan insektisida polydor (lamda sihalotrin) tidak berjalan sesuai SOP dengan rotasi 14 hari sekali.

Gejala serangan $O$. rhinoceros nampak pada daun yang sudah terbuka, ditandai dengan adanya guntingan yang berbentuk huruf $\mathrm{V}$ terbalik sedangkan pada daun yang belum membuka bekas serangan dapat dilihat dari bekas gerekan pada pada daun muda. $O$. rhinoceros dewasa terbang ketajuk tanaman kelapa sawit pada malam hari dan mulai bergerak kebagian salah satu ketiak pelepah daun paling atas dan memakan pelepah daun muda yang belum terbuka, bekas gigitan akan menyebabkan daun seperti tergunting dan jelas terlihat setelah daun terbuka. $O$. rhinoceros dapat menyerang tanaman kelapa sawit yang masih muda maupun yang sudah dewasa. Serangan ini dapat dilakukan O. rhinoceros jantan maupun betina (Bandu, et al.,2017).

Dari hasil pengamatan selama 28 hari, intensitas kerusakan tanaman kelapa sawit sebelum dan sesudah perlakuan dapat dilihat pada Tabel 2 sebagai berikut:

Tabel 2. Intensitas Kerusakan Tanaman Berbagai Aras Perlakuan

\begin{tabular}{|c|c|c|c|}
\hline \multirow{2}{*}{ Blok } & \multirow{2}{*}{ Perlakuan } & \multicolumn{2}{|c|}{ Intensitas Kerusakan (\%) } \\
\hline & & Sebelum & Sesudah \\
\hline \multirow[t]{2}{*}{ B20a } & $\begin{array}{l}\text { Feromon + Insektisida } \\
\text { Polydor }\end{array}$ & 0 & $0,94 b$ \\
\hline & Feromon + Insektisida Jaring & 0 & $0 \mathrm{a}$ \\
\hline \multirow[t]{2}{*}{ B20b } & $\begin{array}{l}\text { Feromon + Insektisida } \\
\text { Polydor }\end{array}$ & 0 & $1,25 b$ \\
\hline & Feromon + Insektisida Jaring & 0 & $\mathrm{Oa}$ \\
\hline \multirow[t]{2}{*}{ B20c } & $\begin{array}{l}\text { Feromon + Insektisida } \\
\text { Polydor }\end{array}$ & 0 & $0,60 \mathrm{~b}$ \\
\hline & Feromon + Insektisida Jaring & 0 & $0 a$ \\
\hline
\end{tabular}

Keterangan : Angka yang diikuti dengan huruf yang sama pada kolom menunjukkan tidak ada interaksi nyata berdasarkan uji DMRT pada jenjang nyata 5\% 
Dari Tabel 2 dapat dilihat bahwa intensitas kerusakan tanaman akibat serangan $O$. rhinoceros sesudah perlakuan feromon+ insektisida polydor menunjukkan hasil yang berbeda nyata karena terjadi peningkatan intensitas kerusakan pada ketiga blok yang menjadi ulangan. Hal ini dikarenakan pada perlakuan feromon+ insektisida polydor terjadi penguapan dan penyucian insektisida polydor yang disemprotkan pada pupus tanaman yang diakibatkan dari terjadinya fluktuasi curah hujan pada bulan Desember 2020 dan Januari 2021. Berikut adalah sebaran curah hujan perhari, dapat dilihat pada Gambar 2 sebagai berikut:

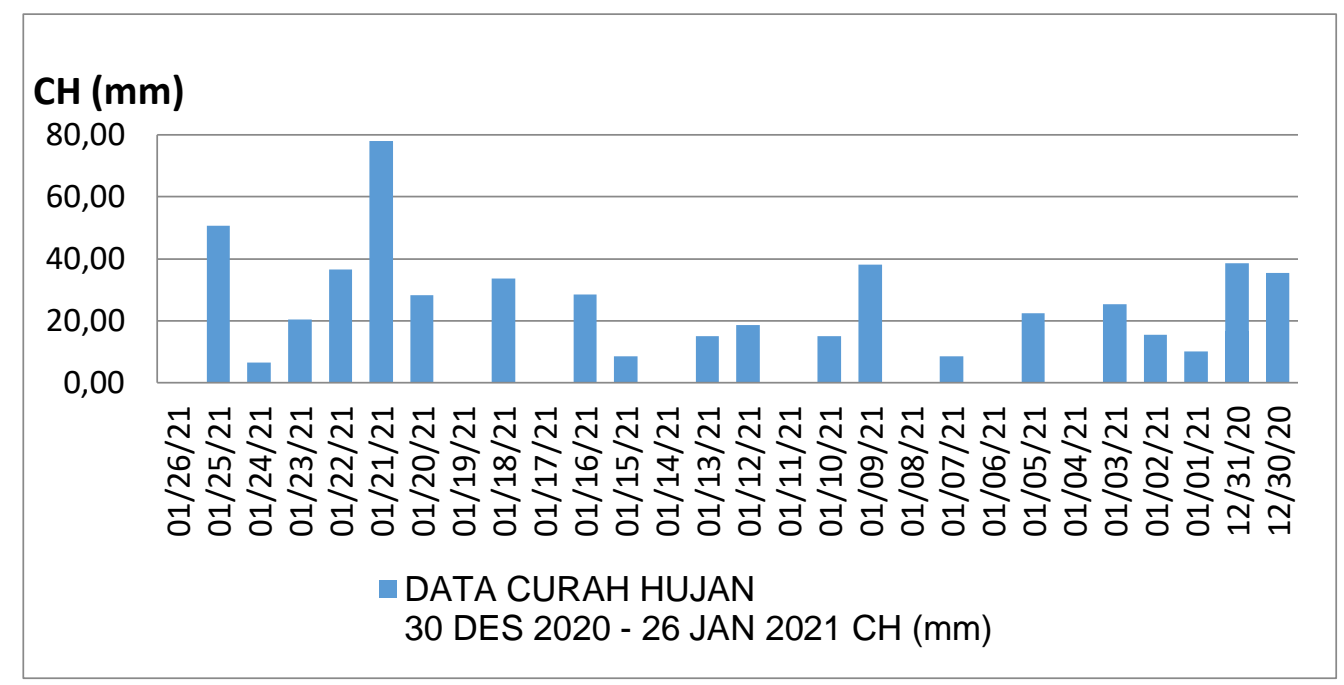

Gambar 2. Grafik Sebaran Curah Hujan Desember 2020 dan Januari 2021

Sumber : Data Curah Hujan KSP, 2021

Berdasarkan grafik sebaran curah hujan dengan rata-rata curah hujan $20.91 \mathrm{~mm}$ perhari, menyebabkan terjadi pencucian insektisida polydor yang memiliki senyawa repellen yang dapat menolak $O$. rhinoceros karena aroma atau bau yang tidak disukai tidak bekerja optimal selama 14 hari. Sehingga memberi kesempatan kepada $O$. rhinoceros untuk hinggap dan menggerek tanaman kelapa sawit (Susanto, et al.,2012).

Pada perlakuan feromon+ perangkap jaring (orynet trap) menunjukkan hasil yang tidak berbeda nyata terhadap intensistas kerusakan sebelum dan sesudah perlakuan. Perangkap jaring (Orynet trap) yang dipasang melingkar pada daerah pupus tanaman kelapa sawit menghalangi kumbang untuk menggerek pupus tanaman. Dengan demikian, perlakuan ini lebih baik dalam menghalau hama $O$. rhinoceros. 

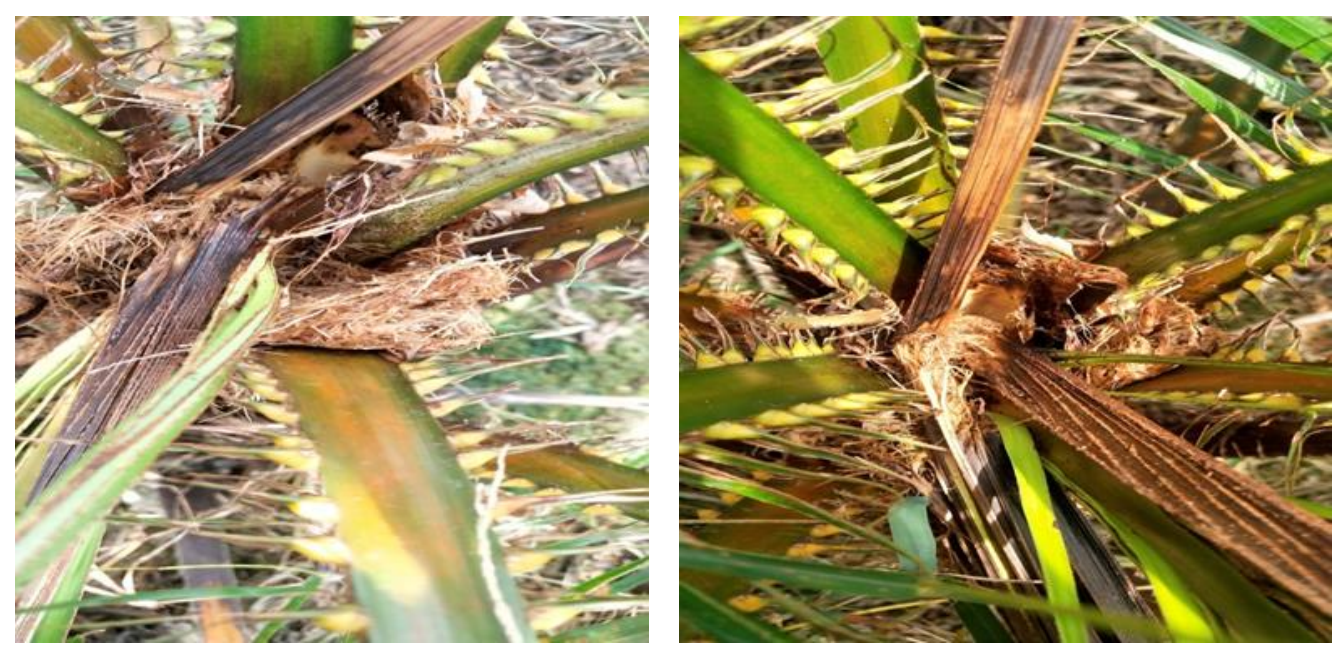

Gambar 3. Gejala serangan O.rhinoceros pada tanaman belum menghasilka

\section{A. Hasil Tangkapan O. rhinoceros Pada Setiap Perlakuan}

Selanjutnya selama pengamatan penelitian, diperoleh hasil tangkapan O. rhinoceros dapat dilihat pada Tabel 3 sebagai berikut :

Tabel 3. Hasil Tangkapan O. rhinoceros Pada Berbagai Aras Perlakuan

\begin{tabular}{|c|c|c|c|c|c|c|}
\hline \multicolumn{7}{|c|}{ Populasi O. rhinoceros (ekor) } \\
\hline \multirow[t]{2}{*}{ Perlakuan } & \multicolumn{4}{|c|}{ Minggu Ke } & \multirow[t]{2}{*}{ Total } & \multirow[t]{2}{*}{ Rerata per Hari } \\
\hline & I & II & III & IV & & \\
\hline $\begin{array}{c}\text { Feromon + Insektisida } \\
\text { Polydor }\end{array}$ & 29 & 114 & 124 & 163 & 430 & $15.4 a$ \\
\hline $\begin{array}{c}\text { Feromon + Insektisida } \\
\text { Jaring }\end{array}$ & 46 & 130 & 149 & 180 & 505 & $18.0 \mathrm{~b}$ \\
\hline
\end{tabular}

Keterangan : Angka yang diikuti dengan huruf yang sama pada kolom menunjukkan tidak ada interaksi nyata berdasarkan uji DMRT pada jenjang nyata $5 \%$

Hasil tangkapan kumbang terbanyak pada perlakuan feromon+perangkap jaring (orynet trap) dengan total tangkapan 18 imago $O$. rhinoceros per hari. sedangkan perlakuan feromon+ insektisida polydor sebesar 15,4 per hari (Tabel 3). Hal ini menunjukkan bahwa dari segi hasil tangkapan, perlakuan feromon+ perangkap jaring (orynet trap) memberikan hasil yang lebih baik dalam memerangkap $O$. rhinoceros dibandingkan dengan perlakuan feromon+ insektisida polydor.

Jenis perlakuan perangkap dengan feromon sintetik (ethyl 4- methyloctanoate) yang digunakan merupakan jenis feromon agregasi kimia yang dikeluarkan oleh serangga untuk menarik serangga jantan dan betina untuk berkumpul, mencari pasangan dan dilanjutkan 
dengan kopulasi. Penggunaan feromon agregasi (ethyl 4- methyloctanoate) memiliki tingkat keampuhan dalam memerangkap O. rhinoceros mencapai 95\% (Widyanto, 2014).

Perangkap feromon yang dikombinasikan dengan insektisida polydor dan perangkap jaring (orynet trap) menunjukkan peningkatan terhadap hasil tangkapan O. rhinoceros dalam setiap minggu pengamatan dapat dilihat pada Gambar 4.

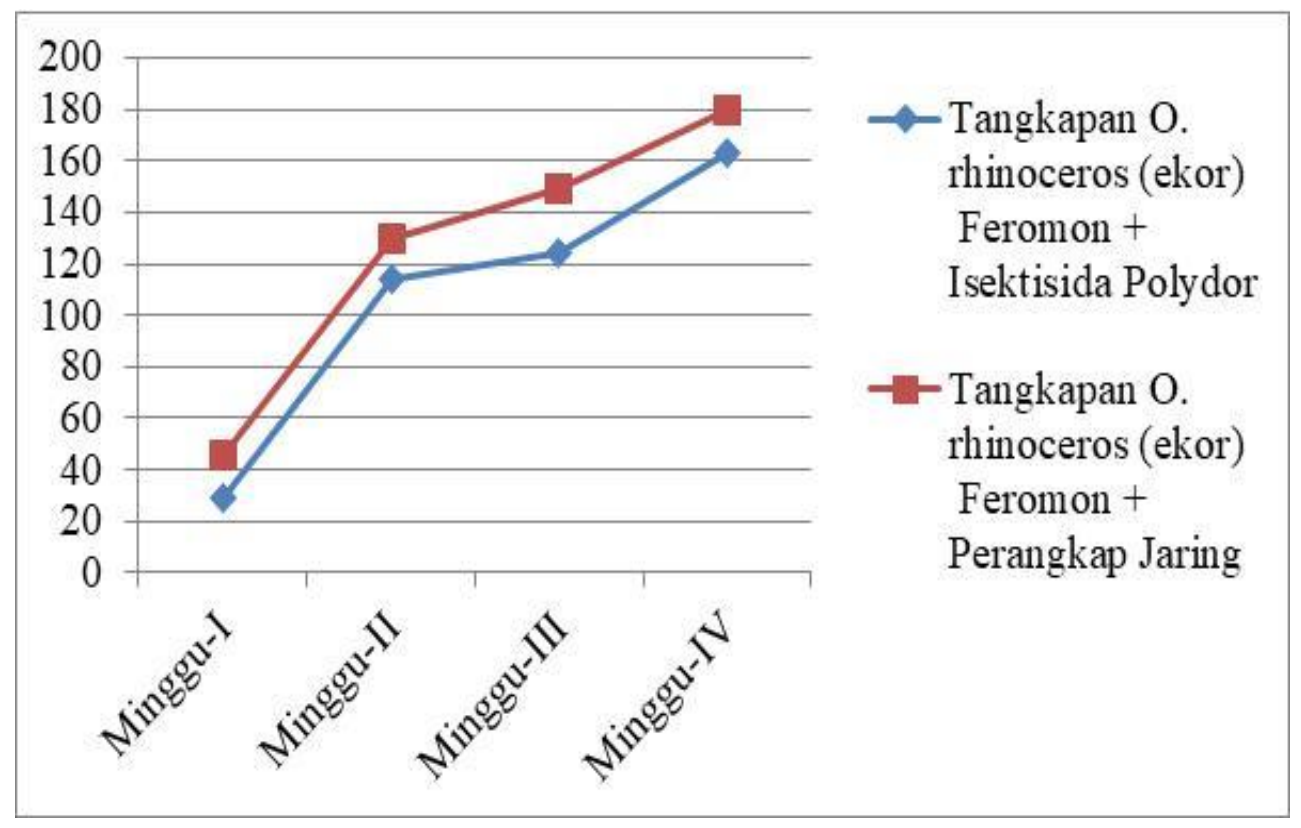

Gambar 4. Grafik Hasil Tangkapan O. rhinoceros Per Minggu

Sumber : Data Hasil Pengamatan Penulis

Jenis perlakuan feromon + insektisida polydor memiliki hasil tangkapan O. rhinoceros sebesar $95 \%$ pada feromon trap dan hanya $5 \%$ pada perlakuan insektisida polydor. Pada perlakuan feromon+perangkap jaring (orynet trap) sebesar $81,4 \%$ pada feromon trap dan $18,6 \%$ pada perangkap jaring (orynet trap).

Lebih rendahnya hasil tangkapan imago $O$. rhinoceros pada perlakuan feromon+ insektisida polydor dikarenakan insektisida polydor yang merupakan insektisida racun kontak dan lambung yang berbentuk pekatan berwarna kuning jerami jernih yang dapat menyebabkan saluran natrium selalu terbuka, sehingga pada beberapa kasus menyebabkan reaksi berlebihan oleh saraf. Saluran natrium ini terlibat dalam penyebaran info potensial disepanjang akson saraf (Redaksi, 2014).

Secara fungsi pengaplikasian insektisida polydor berfungsi sebagai perlindungan pada tanaman karena memiliki senyawa repellen yang merupakan zat kimia yang dapat mengusir $O$. rhinoceros karena aroma menyengat yang dihasilkan tidak disukai oleh $O$. rhinoceros. Penulis hanya dapat menemukan $O$. rhinoceros pada pengamatan minggu ke dua dan empat pada pokok sampel yang diberikan perlakuan insektisida polydor. Hal tersebut terjadi akibat menurunnya reaksi aroma bau menyengat yang tidak disukai $O$. rhinoceros akibat pencucian 
oleh air hujan dan penguapan pada minggu ke dua setelah aplikasi, dan O. rhinoceros yang ditemukan sudah dalam keadaan mati karena terkena racun lambung kontak ini (Gambar 4 )

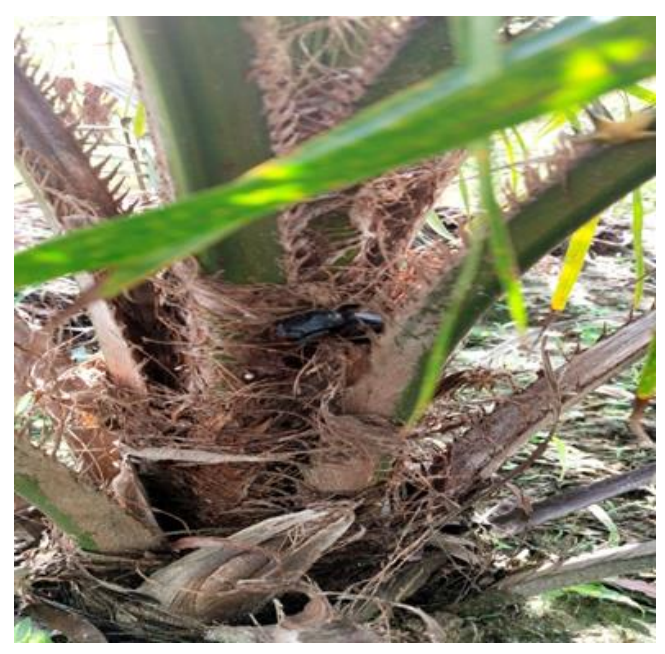

a

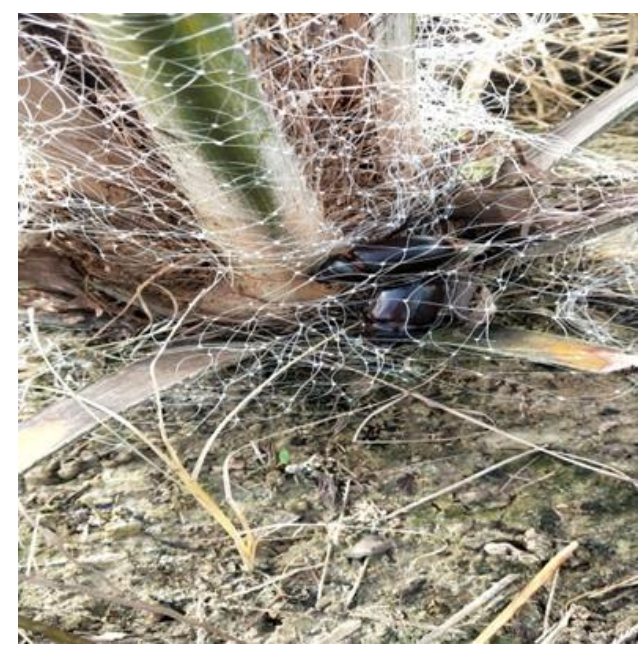

b

Gambar 4. Tangkapan O.rhinoceros pada perlakuan feromon + insektisida polidor (a) dan feromon + jaring (orynet trap (b)

Pada perlakuan feromon+ perangkap jaring (orynet trap) dapat ditemukan tangkapan $O$. rhinoceros pada setiap minggu pengamatan. Hal tersebut terjadi karena pada perangkap jaring (orynet trap) yang dipasang melingkar pada pupus tanaman kelapa sawit memiliki fungsi untuk melindungi pupus tanaman kelapa sawit dari serangan $O$. rhinoceros dapat memerangkap $O$. rhinoceros sehingga $O$. rhinoceros menjadi tersangkut pada jaring dan tidak dapat menjangkau pupus tanaman kelapa sawit. Hal ini juga berbanding lurus dengan tidak terjadinya penambahan intensitas kerusakan akibat dari perlakuan ini. Untuk itu perlakuan feromon+ perangkap jaring (orynet trap) merupakan perlakuan yang lebih baik dalam memerangkap imago dewasa $O$. rhinoceros.

\section{B. Jumlah Tangkapan O. rhinoceros Jantan dan Betina (ekor) Pada Setiap Perlakuan}

Hasil pengamatan tangkapan $O$. rhinoceros jantan dan betina pada setiap perlakuan dihitung dengan cara membagikan antara jumlah imago betina $O$. rhinoceros terperangkap dengan jumlah imago jantan terperangkap. Hasil dari jumlah tangkapan O. rhinoceros jantan dan betina dilihat pada Tabel 5 sebagai berikut : 
Tabel 4. Jumlah Tangkapan O. rhinoceros Jantan dan Betina pada Berbagai Perlakuan

\begin{tabular}{|c|c|c|c|c|}
\hline \multirow{2}{*}{ Perlakuan } & \multicolumn{2}{|c|}{$\begin{array}{l}\text { Jumlah O. rhinoceros } \\
\text { Terperangkap (ekor) }\end{array}$} & \multicolumn{2}{|c|}{ Seks rasio } \\
\hline & $0^{x}$ & q & $\sigma^{x}$ & q \\
\hline $\begin{array}{r}\text { Feromon + Insektisida } \\
\text { Polydor }\end{array}$ & 29 & 114 & 1 & 3.674 \\
\hline $\begin{array}{r}\text { Feromon + Insektisida } \\
\text { Jaring }\end{array}$ & 46 & 130 & 1 & 3.676 \\
\hline Rerata & 100 & 367,5 & 1 & 3.675 \\
\hline
\end{tabular}

Pada Tabel 4, dapat dilihat bahwa jumlah imago 0 . rhinoceros betina yang tertangkap lebih banyak dari semua perlakuan. Sex ratio jantan dan betina adalah $1: 3$ atau $21,4 \%$ : $78,6 \%$.

Pada perlakuan feromon + insektisida polydor dan feromon+ perangkap jaring (orynet trap) keduanya menggunakan feromon agregasi sintetik dengan senyawa kimia ethyl 4 methylactonoat. Ethyl 4-methyloctanoate merupakan senyawa feromon agregasi yang dihasilkan oleh $O$. rhinoceros jantan. Maka dengan penggunaan feromon ini akan lebih menarik serangga betina (Sahetapy, et al., 2018). Hal ini diperkuat oleh Pusat Penelitian Kelapa Sawit (2004), menyatakan bahwa kumbang O. rhinoceros yang terperangkap pada perangkap feromon agregasi lebih banyak betina dari pada jantan. Hasil penelitian PPKS (2007) juga menyatakan bahwa penggunaan perangkap feromon lebih banyak O. rhinoceros betina yang terperangkap daripada kumbang jantan dengan perbandingan 60-80\% betina dan 20-40\% jantan fluktuasi kumbang jantan (Susanto, et al.,2012).

Penggunaan feromon yang dikombinasikan dengan insektisida polydor dan perangkap jaring (orynet trap) dapat mengakibatkan penurunan populasi O. rhinoceros di lapangan pada generasi berikutnya, hal ini disebabkan oleh adanya perubahan laju natalitas. Salah satu faktor utama penentu laju natalitas adalah rasio seks. Rasio seks pada kebanyakan serangga populasi adalah 1:1, jantan terhadap betina (Hadi, 2009). Namun dengan penggunaan feromon yang dikombinasikan dengan insektisida polydor dan perangkap jaring (orynet trap) terjadi perubahan rasio seks di lapangan yakni menjadi 1:3,6 jantan terhadap betina, dikarenakan feromon menarik $78,6 \%$ betina sedangkan jantan hanya $21,4 \%$. Berkurangnya betina di lapangan dapat mengakibatkan penurunan kelahiran individu baru, dikarenakan terjadi gangguan pada proses mating (perkawinan serangga). Diperkuat oleh Hadi (2009) yang menyatakan bahwa dengan adanya perubahan proposi imago betina di lapangan menyebabkan perubahan laju natalitas. 


\section{KESIMPULAN}

Berdasarkan hasil penelitian dapat disimpulkan bahwa penggunaan feromon dengan perangkap jaring (orynet trap) lebih efektif dari pada penggunaan feromon dengan insektisida polydor. Namun demikian, perlu dikaji lebih lanjut dari segi biaya apabila diaplikasikan dalam jumlah besar dan berbagai aspek lainnya..

\section{DAFTAR PUSTAKA}

Anonim, (2015). Statistik Perkebunan Kelapa Sawit Indonesia 2013-2015. Kementerian Pertanian Republik Indonesia. Jakarta.

Anonim, (2016). Pestisida Pertanian dan Kehutanan. Direktorat Pupuk dan Pestisida Direktorat Jendral Prasarana dan Sarana Pertanian Kementrian Pertanian Republik Indonesia. www.ghbook.ir/index.com.

Bandu, M. L., Tarore, D., \& Tairas, R. W. (2017). Pest Beetle Attack (Oryctes rhinoceros L.) On Coconut Plants (Cocos nucifera L.) In Mapanget Talawaan Subdis. Fakultas Pertanian Universitas Samratulangi, Manado, Makasar.

Beetle, C. R. (2015). Coconut

Rhinoceros Beetle Program. University of Guam Behavior \& Biology. (671).

Budi, M. (2015). Makalah Budidaya Tanaman Kelapa Sawit. Jurnal Unik Spesial, (April).

Fauzi, Y. (2012). Kelapa Sawit. Edisi Revisi, Penebar Swadanya, Jakarta.

Francisco, A. R. L. (2013). No Title. Journal of Chemical Information and Modeling. 53(9), 1689-1699.

Hadi, MH, U Tarwotjo, dan R Rahadian. 2009. Biologi Insekta Entolomogi. Graha IImu. Yogyakarta. $162 \mathrm{p}$.

Hamdani, Yaherwandi dan Trizelia. (2011). Potensi Cendawan Entomopatogen Indigenus Sebagai Pengendali Hayati Hama Penggerek Buah Kakao Conomorpha cramerella SNELL. Jurnal Manggaro Vol. 12 (2) $75-80$.

Hamilton, H. (2007). Pengendalian Hama Kumbang (Oryctes rhinoceros) pada kelapa sawit. Jurnal Perlindungan Tanaman Indonesia, 2(32), 1-9.

Hasibuan, S. (2018). Pengendalian Kumbang Badak (Oryctes rhinoceros L; Scarabaeidae) dengan Perangkap Warna Pada Perkebunan Kelapa Sawit TBM 1 di Perkebunan Gunung Bayu. Fakultas Pertanian Universitas Asahan, Sumatra Utara. (November), 344-351.

Herlinda, S. (2018). Development of Biological Control for Pests of Oil Palm and Rice-CornSoybean. Prosiding Seminar Nasional Lahan Suboptimal 2018, Palembang 18-19 Oktober 2018, 978-979.

Junaedi, Bakti dan Zahara. (2015). The Predation of Myopopone Castaneae (Hymenoptera: Formicidae) to Larvae of Oryctes Rhinoceros L. Fakultas Pertanian Universitas Sumatra Utara, Medan. Agroekoteknologi, 3(1), 112-

Lobalohin, S., Saartje, H.N. dan Jeffij, V.H. (2014). Kerusakan Tanaman Kelapa (Cocos nucifera,L.) Akibat Serangan Hama Sexava sp dan O.rhinoceros di Kecamatan Teluk Elpaputih Kabupaten Maluku Tengah. Jurnal Budidaya Pertanian, 10(01): 35-40. 
Lubis, M. F., dan Lubis, I. (2018). Production Analysis of Oil Palm (Elaeis guineensis Jacq.) in Pelalawan, Riau. Buletin Agrohorti, 6(2), 281. https://doi.org/10.29244/agrob.6.2.281286. Bogor Agricultural University. Bogor.

Luhukay, R., Sahetapy, B., dan Umasangadji, A. (2017). Effectivity of Some Types of Traps on the Horn Beetle (Oryctes rhinoceros L.) (Coleoptera: Scarabaeidae). Jurnal Budidaya Pertanian, 13 (1), 30. Fakultas Pertanian, Universitas Pattimura. Ambon.

Manley, M., Melzer, M. J., dan Spafford, H. (2018). Oviposition preferences and behavior of wild-caught and laboratory-reared coconut rhinoceros beetle, oryctes rhinoceros (Coleoptera: Scarabaeidae), in relation to substrate particle size. Insects, 9(4). Department of Plant and Environmental Protection Sciences, University of Hawai'i at Mānoa.

Pertami, A. R. P. (2016). Intensitas Serangan Oryctes Rhinoceros Pada Tanaman Kelapa Di Jepara. 5-12. Fakultas Matematika dan Ilmu Pengetahuan Alam, Universitas Negeri Semarang.

Widyanto, H., Saputra, S., dan Suryati (2012). Control Of Horn Beetle (Oryctes Rhinoceros Linn) Using Feromon Traps For Oil Palm (Elaeis Guineensis Jacq) on Peatland in Riau. (Juni), 195-204. Balai Pengkajian Teknologi (BPTP) Riau, Pekanbaru.

Purba, J. H. V, dan Sipayun, T. (2017). Perkebunan Kelapa Sawit Indonesia Dalam Perspektif Pembangunan Berkelanjutan. Masyarakat Indonesia, 43(1), 81-94.

Purba, Y.R. (2010). Pemanfaatan Tandan Kosong Sawit Sebagai Perangkap O.rhinoceros (L.) Di Perkebunan Kelapa Sawit. Jurnal Penelitian Kelapa Sawit. http//:www.google.com. Diakses tanggal 16 Oktober 2019.

Putri, R. I. P. (2016). Uji Patogenitas Jamur Metarhizium anisopliae terhadap Mortalitas Larva Oryctes rhinoceros L. 1-16. Fakultas Matematika dan Ilmu Pengetahuan Alam, Universitas Negeri Semarang.

Redaksi, A. K. K. (2014). Cara kerja dan daftar pestisida serta strategi pergilirannya pada budidaya tanaman sayuran dan palawija. (December).

Sahetapy, B., Masauna, E. D., \& Luhukay, R. (2018). Uji Efektivitas Perangkap Feromon Terhadap Hama Oryctes rhinoceros L. dan Intensitas Kerusakan pada Tanaman Kelapa di Desa Latuhalat, Kecamatan Nusaniwe, Pulau Ambon.

Sitinjak, S. E. (2018). Test The Effectiveness Of Entomopatogenic Fungi Metarhizium anisopliae and beauvaria bassiana On Larvae Of Horn Beet (Oryctes rhinoceros) to Mortality On Chipping Of Oil Palm Stems. Universitas Medan Area, Medan.

Susanto, S., Prasetyo, E. A., Priwatama, H. S., \& Roziansyah, A. T. (2012). Buku Pengendalian Terpadu Oryctes rhinoceros L. Pusat Penelitian Kelapa Sawit, Indonesian Palm Oil Research Institute. Medan, Sumatera Utara.Threat, A. M., \& Trees, P. (2014). Coconut Rhinoceros Beetle, Oryctes rhinoceros Topics to Be Covered. University of Hawaii at Manoa.

Widyato, H. (2014). 13 Pengendalian Hama. For T. Palm Oil Riau - Copy. (Juni), 195-204.

Widyanto, H., Saputra, S., dan Suryati (2012). Control Of Horn Beetle (Oryctes Rhinoceros Linn) Using Feromon Traps For Oil Palm (Elaeis Guineensis Jacq) on Peatland in Riau. (Juni), 195-204. Balai Pengkajian Teknologi (BPTP) Riau, Pekanbaru. 